\title{
Discipulado y sacerdocio a la luz de la carta a los Hebreos
}

JOSÉ IGNACIO BLANCO

FORMADOR, IEME

DOI: https://doi.org/10.52039/seminarios.v54i189-190.529

La presente comunicación me viene sugerida por la misión pastoral. En ella me encuentro con frecuencia con el reto de acompañar a hermanos sacerdotes y candidatos al sacerdocio. Misión pastoral que realizo a caballo entre Zaragoza, mi diócesis y la diócesis de Ciudad Bolívar en territorio venezolano.

En esta misión de acompañar me encuentro con personas que viven con gozo su ministerio, otras con cierta desilusión, otras con desencanto. Entre los candidatos al ministerio ordenado me encuentro de todo: personas con ilusión, seducidos por la persona de Jesús, por los valores que Él encarna (justicia, verdad, cercanía a los pobres, misericordia...), personas con miedo a dialogar con un mundo secularizado (especialmente en España) que tienen a refugiarse en el culto, personas barnizadas por ideologías poco abiertas, personas bañadas por ideologías progresistas...

Entre sacerdotes y candidatos al sacerdocio, sin embargo, empiezo a percibir algún elemento común que constituye una especie de sintonía de algo más hondo: miedo a hacer un camino de libertad con Cristo Jesús, miedo a una relación de amor vinculante y afectivo con Él, resistencias a dejarse amar por Dios y por Jesús. Incluso percibo que la mayor parte de energías pastorales no pasan de la primera etapa del ministerio público de Jesús de Nazaret: llegan a identificarse con Jesús y sus valores hasta 
el Tabor. Pero, en cuanto hay que dejarse vincular con Él en el camino hacia Jerusalén (que Jesús emprendió con determinación [Lc 9, 51]), da la impresión que el miedo aflora con mayor fuerza y Jesús ya empieza a asustar. Mejor, asusta el camino que asume Jesús y que los discípulos no entienden o no pueden entender.

Por eso, y dentro de las limitaciones de una comunicación, ofrezco algo que vengo trabajando hace algún tiempo: la relación entre discipulado y sacerdocio.

\section{Jesús, Sumo Sacerdote de la Nueva Alianza}

La estructura literaria de la carta a los Hebreos hace aparecer tres núcleos temáticos abordados por su autor: una eclesiológico, otro escatológico y un tercero, en posición central, sacrificial.

Poner en evidencia el carácter sacerdotal del misterio pascual de Jesucristo es la originalidad de esta carta. Tarea nada fácil en un ambiente en que el sacerdocio era percibido a la luz del sacerdocio levítico, restaurado de forma especial después del regreso y experiencia del exilio en Babilonia.

En la época del postexilio han quedado testimonios veterotestamentarios de que el acceso al sumo sacerdocio se realizaba con métodos más bien obscenos: el hermano del sumo sacerdote Onías usurpó el sumo pontificado, después de haber prometido al rey, en una conversación, trescientos sesenta talentos de plata y ochenta talentos de otras rentas (2 Mac 4, 7-8). Este sujeto, llamado Jasón, fue suplantado pronto por Menéalo que logró ser investido del sumo sacerdocio, ofreciendo trescientos talentos de plata más que Jasón (2 Mac 4, 24). Surgió la rivalidad que llegó al asesinato (3 Mac 4, 32-34).

Por otro lado, en la concepción judía del sacerdocio, se exigía para el sumo sacerdote el cumplimiento riguroso de bastantes separaciones legales. Exigir del sumo sacerdote una asimilación completa con los demás miembros del pueblo judío habría sido para ellos un contrasentido inaceptable ${ }^{1}$.

Por eso, el contraste entre el sacerdocio judío y el sacerdocio de Jesucristo, resulta especialmente chocante. El autor de la carta a los Hebreos, sin embargo, no hace teología del sacerdocio cristiano a partir de una reflexión teológica. Son los hechos, mejor, el ACONTECIMIENTO PASIÓN, MUERTE Y RESURRECCIÓN, los que hacen percibir al autor

1 VANHOYE, A. Sacerdotes antiguos, sacerdocio nuevo según el Nuevo Testamento. Ed. Sígueme, Salamanca, 1984, p. 85. 
de este documento precioso, la novedad del sacerdocio de Jesucristo: fue su entrega obediente a la voluntad del Padre el camino que le lleva a la glorificación y a ser constituido Sumo Sacerdote de la Nueva Alianza (Heb 2, 17-18).

La brevedad de esta comunicación me impide aportar más elementos de fundamentación. Pero, la síntesis que ofrece el autor de la carta a los Hebreos es que el fundamento del sacerdocio de Jesucristo se encuentra en su obediencia filial a la voluntad del Padre. Y la forma por la que accede al Sumo Sacerdocio es la entrega existencial de su propia persona y su solidaridad con los pecadores.

\section{Naturaleza del sacerdocio cristiano}

Los documentos del Concilio Vaticano II que afrontan el tema del sacerdocio (Presbyterorum ordinis y Optatam totius) no abordaron con claridad el tema de la identidad del sacerdocio. Eso explica la necesidad que experimentó Juan Pablo II de dedicar varios Sínodos episcopales a este asunto.

Me detengo brevemente en la exhortación Apostólica Pastores dabo vobis (1992), pues en ella dedica algún número a la naturaleza del sacerdocio.

En este documento de tipo preferentemente pastoral, afirma Juan Pablo II, recogiendo sugerencias y debates del sínodo de los obispos, que existe una ligazón ontológica entre el sacerdote y Cristo, Sumo Sacerdote y Buen Pastor2.

El Papa recoge dos títulos aplicados a Cristo: uno procede de la carta a los Hebreos (Sumo Sacerdote) y el otro del evangelio de Juan (Buen Pastor) (Jn 10).

Pero el desarrollo posterior de la exhortación apostólica olvida inmediatamente el título de Sumo Sacerdote para centrarse en el de Buen Pastor.

\section{A propósito de ambos títulos}

La imagen de Buen Pastor, como he apuntado más arriba, procede de Juan 10, donde Jesús se autopresenta como Buen/auténtico Pastor frente a los fariseos con quienes, en el capítulo 9, acaba de tener una con-

${ }_{2} \mathrm{PDV}, \mathrm{n}^{\circ} 11$ 
frontación dura a propósito de la curación del ciego de nacimiento, donde los fariseos dicen de todo menos bonito al ciego, a sus padres $\mathrm{y}$, por supuesto, a Jesús.

EI AT llama pastores a los jefes políticos del pueblo. En la época de los Jueces son éstos; en la época monárquica, lo son los reyes. En la época del postexilio lo son los dirigentes. En tiempos de Jesús, exceptuando los pastores a los que se anuncia el acontecimiento del nacimiento del Mesías (Lc 2, 8), se aplica el título pastores a las autoridades del pueblo judío. En este caso a los fariseos.

Por tanto, el tema del pastoreo es un asunto de autoridad. $\mathrm{Y}$ el capítulo 10 de Juan pone en boca de Jesús dos tipos de autoridad: aquella que se impone por la fuerza y genera muerte (viene el lobo y las dispersa y mata) y otro tipo de autoridad, ejercida por el propio Jesús, que es la autoridad que, entregándose Él mismo por las ovejas, genera vida: he venido para que tengan vida y la tengan abundante (Jn 10, 10).

El título de sumo sacerdote hace referencia a la perfección alcanzada por su entrega obediente y orante a la voluntad del Padre (Heb 5, 9). Desde su entrada en el mundo Jesucristo asumió como misión cumplir la voluntad de Dios (Heb 10, 5-9; Jn 4, 34; 6, 38; 8, 29). Aprendizaje de la obediencia y acogida de la oración a quien podía librarlo de la muerte (Heb $5,7)$ se unen así en el nivel más profundo. La acción de Cristo consiste en solicitar la acción de Dios en la oración y en acogerla en la obediencia. Constituido Sumo Sacerdote por Dios mismo, este sumo sacerdocio se fundamenta en la salvación que, con su obediencia hasta la muerte, ofrece a todos.

\section{Discipulado y sacerdocio}

A la luz de estas consideraciones ofrecidas por la Revelación, resulta necesario integrar los dos títulos que el Magisterio de la Iglesia, en palabras de Juan Pablo II, atribuye a la naturaleza del sacerdocio ministerial.

Si se insiste en el sacerdote como partícipe del sacerdocio de Jesucristo, Cabeza y Pastor, el peligro reside en el modo de ejercer dicho pastoreo. En otras palabras, en el modo de ejercer la autoridad ministerial que el sacramento del Orden otorga.

Si se insiste en el ministerio sacerdotal como participación del Sumo Sacerdocio de Jesucristo, el peligro se encuentra en ejercerlo al modo judaico: separados, puros, sin defecto ni físico ni moral, formando una especie de casta aparte que termina por olvidarse de las miserias propias y ajenas. 
A mi juicio, y a la luz de la carta a los Hebreos, el punto que permite integrar la vivencia del sacerdocio ministerial tal como la Revelación lo propone se encuentra en la obediencia de fe.

Los textos evangélicos, especialmente sinópticos, que recogen los rasgos del discípulo y que vienen reflejados a partir de la experiencia del Tabor, van poniendo en evidencia el itinerario del discípulo. Hasta el Tabor Jesús ha asociado a los discípulos a su misión mesiánica que, paradójicamente, es rechazada. A partir del Tabor, Jesús ya no asocia a sus discípulos solamente a su misión sino a su destino de sufrimiento y muerte. Va exigiendo obediencia de fe en correlación a la obediencia filial que el mismo Jesús vive con el Padre.

Si excluimos del ministerio ordenado este elemento de obediencia de fe, estamos excluyendo del sacerdocio ministerial los rasgos propios del discípulo y, en concreto, la obediencia de la fe que se traduce en los mismos rasgos del Sumo Sacerdote de la Nueva Alianza: Jesucristo. Estos rasgos no son otros que la entrega existencial de su persona (y no de sacrificios rituales que no pueden perdonar pecados ni generar vida) y la solidaridad con los pecadores por los cuales Dios ha enviado a su propio Hijo (apostolós). 